NBER WORKING PAPER SERIES

\title{
WHO BENEFITS FROM TAX-ADVANTAGED EMPLOYEE BENEFITS?: EVIDENCE FROM UNIVERSITY PARKING
}

\author{
Michael D. Grubb \\ Paul Oyer \\ Working Paper 14062 \\ http://www.nber.org/papers/w14062
NATIONAL BUREAU OF ECONOMIC RESEARCH
1050 Massachusetts Avenue
Cambridge, MA 02138 \\ June 2008
}

We thank many university parking office employees for providing data from their schools. Grubb thanks SIEPR's Taube Scholarship Fund Fellowship and the State Farm Companies Doctoral Award for financial support. The views expressed herein are those of the author(s) and do not necessarily reflect the views of the National Bureau of Economic Research.

NBER working papers are circulated for discussion and comment purposes. They have not been peerreviewed or been subject to the review by the NBER Board of Directors that accompanies official NBER publications.

(C) 2008 by Michael D. Grubb and Paul Oyer. All rights reserved. Short sections of text, not to exceed two paragraphs, may be quoted without explicit permission provided that full credit, including $\odot$ notice, is given to the source. 
Who Benefits from Tax-Advantaged Employee Benefits?: Evidence from University Parking Michael D. Grubb and Paul Oyer NBER Working Paper No. 14062

June 2008

JEL No. H25,H32,J32,K35,K49

\begin{abstract}
$\underline{\text { ABSTRACT }}$
We use university parking permits to study how firms and employees split the value of employee benefit tax subsidies. Starting in 1998, the IRS allowed employees to pay for parking passes with pre-tax income. This subsidized the parking pass purchases of faculty and staff, but did not affect students. We show that the typical university raised its parking rates by 8-10\% extra when it implemented a pre-tax payment system, but that this increase was the same for those affected by the tax change and those that were not affected. We conclude that university employees captured much of the new tax benefit, that faculty and staff that purchase permits benefited relative to those that do not purchase permits, and that students that purchase permits were made worse off relative to those that do not buy permits. We discuss what these results suggest about universities' objectives in setting their parking prices and about the demand for university parking.
\end{abstract}

Michael D. Grubb

MIT Sloan School of Management

50 Memorial Drive, E52-432

Cambridge, MA 02142-1347

mgrubb@mit.edu

Paul Oyer

Graduate School of Business

Stanford University

518 Memorial Way

Stanford, CA 94305-5015

and NBER

pauloyer@stanford.edu 


\section{Introduction}

Firms provide a variety of benefits to their employees. In addition to the often-studied examples of health insurance and pensions, many employers also provide meals, product discounts, and numerous other benefits. There are several motivations for firms to provide these benefits, but one important consideration in almost all benefits decisions is taxes. ${ }^{1}$ Firms and employees can save on taxes if the firm provides a benefit to the employee and the employee is not required to report the value of the benefit as income. In this paper, we use prices of parking passes at universities to investigate how the benefits of these tax advantages get split between firms and employees.

If the labor market were perfectly competitive and either tastes for the benefit were homogeneous or firms could adjust individuals' compensation such that each person "paid" for the amount of the benefit she consumed, then employees would capture none of the tax advantages of workplace benefits. In fact, if the product market were also competitive, consumers would capture the benefit. But if employee valuations of the benefit differ, and the firm cannot perfectly price discriminate between employees, then some of the value of the tax advantage will be distributed unequally among employees rather than being captured by the firm or consumers.

We show that, at least in the case of university parking, employees capture a substantial share of the tax advantages of benefits. We focus on an IRS tax code implemented in 1998. This change allowed employers to set up payroll deduction schemes so that employees could pay for parking with pre-tax dollars whereas parking was previously paid out of after-tax income. As a result, if a university charged $\$ 100$ for a parking pass and an employee had a marginal tax rate of $25 \%$, the employee had to earn a total of $\$ 133$ to pay for parking before the change but only $\$ 100$ after. The tax change did not affect students, so we are able to compare changes in staff and faculty rates to changes in student rates.

We show that the tax change led universities to raise their parking prices, but that they let employees who buy parking passes capture a significant share of the tax advantage. We find that, while parking rates go up somewhat as the tax advantage becomes available, the increases are on the order of only $8-10 \%$. We show that the benefits are not split evenly

\footnotetext{
${ }^{1}$ See Oyer (2008) for a discussion of the factors that lead firms to offer employee benefits and Marino and Zabojnik (2008) for a discussion of optimal pricing of employee benefits.
} 
among employees. While universities capture some (but not much) of the benefit of the tax law change through higher prices, we find absolutely no evidence that the tax-changeinduced price increases are greater for faculty and staff than for students. Universities appear to increase their prices across the board despite the fact that $87 \%$ of universities in our sample price discriminate between faculty and students. This leaves most faculty and staff that buy parking passes after the change better off than before the change and leaves most students that buy passes before the change worse off. It appears that faculty and staff permit purchases impose a pecuniary externality on students by driving up student permit prices.

We must qualify our results given some important data limitations. We do not observe how wages change when parking prices change. We cannot say for sure that universities do not capture some of the benefits of the tax law through lower wages. ${ }^{2}$ Also, we do not observe how tuition rates or spending on student services change when parking prices change. We cannot be sure that students facing higher parking prices are not compensated through lower tuition or improved campus services. However, we believe it is safe to conclude that employees captured a considerable amount of the value of the parking law change, that faculty and staff that buy parking passes benefited relative to those that do not buy parking passes, and that the tax law change made students that buy parking passes worse off relative to those that do not.

Our results relate to numerous prior papers in public finance that have studied how the rents from government subsidies and tax policies get split and how those policies can affect parties they were not meant to affect. Poterba (1984), for example, shows that the mortgage interest deduction lowers the cost of home ownership and that this is especially true when inflation is high. As a result, periods of high inflation, even holding the tax rate constant, may lead to increases in the owner-occupied housing stock. Susin (2002) also looks at the housing market, though he focuses on the effects of government vouchers on the rental housing market. He finds that vouchers increase prices for low income renters and, therefore, are costly to those who are not eligible for government vouchers. This combination of results

\footnotetext{
${ }^{2}$ However, in all our correspondence with university parking officials, we never heard any suggestion that parking prices affect wages. Also, we have yet to find a university employee that knew the parking rates and policies at their school before accepting a job. This suggests that universities cannot take the value of the tax out of wages without making their employment offers look less attractive.
} 
mirrors the effects of the parking tax change that we find on faculty and students. Goolsbee (1998a) finds that increases in government $R \& D$ spending have little effect on actual $R \& D$ output because scientists capture most of the additional spending in higher salaries. Both Susin (2002) and Goolsbee (1998a) argue that inelasticity in the relevant markets drives the effects. Berger (1993) also finds that some of the benefits of government R\&D subsidies accrue to providers of R\&D inputs. Goolsbee (1998b) shows that the U.S. investment tax credit had the unintended effect of increasing the price of capital goods, at least in the short term, as producers extracted some of the value of tax subsidies until supply could respond. Andreoni and Payne (2003) find that government donations to charities do not all get used for their intended purposes because the charities respond by reducing other fund-raising efforts.

The $8-10 \%$ increase in university parking prices following the tax law change is smaller than might be expected. Given heterogeneous tax rates and parking values among its employees and an inability to perfectly price discriminate, no university could be expected to extract all value from the tax benefit. Nevertheless, it seems likely that universities could have extracted more value through a larger price increase. Unfortunately, we have very little information on parking quantity, so we cannot say for sure that universities are not in fact capturing some of the value through higher quantity.

After laying out our empirical findings, we consider alternative explanations. We focus on three main possibilities - highly elastic parking demand, a significant "salience" problem, and the possibility that university parking departments employ average cost pricing policies. While there are demand functions that can reconcile our empirical results with university parking departments acting to maximize profits, we argue that this is unlikely. Salience is a possible contributing factor, though we would expect universities to counter this with aggressive marketing campaigns. Finally, though it is hard to reconcile with a standard economic model of universities maximizing profits or social welfare, the patterns we see are consistent with university parking departments practicing average cost pricing, as Shoup (2005) suggests. $^{3}$

\footnotetext{
${ }^{3}$ Our paper adds to the small set of economic studies of parking. Shoup (2005) provides interesting institutional details on university parking systems, with a focus on UCLA. Arbatskay, Mukhopadhaya and Rasmusen (2006) use a parking lot as an example of how rents get distributed when agents fight for access to an underpriced good. They argue that welfare will be higher if parking lots are built larger than mean demand. Fisman and Miguel (2007) use diplomats' parking tickets as an indication of social norms in the
} 


\section{University Parking Pass Background}

\subsection{Tax Code Change}

Many American universities sell parking permits to faculty, staff, and students. Before 1998 employees had to pay for these permits with "after-tax income." ${ }^{4}$ However, ever since passage of the Taxpayer Relief Act of 1997 (TRA-97), universities can deduct the price of parking permits from employees' income. Employees then pay taxes based on their gross wages minus the parking permit price. TRA-97, which added the parking benefit, and the Transportation Equity Act for the 21st Century (TEA-21) Section 9010(a), which applied to other transit benefits such as commuter vans and mass transit passes, revised Internal Revenue Code (IRC) Section 132(f) effective January 1, 1998. IRC 132(f) defines "qualified transportation fringe" benefits provided by an employer to an employee that are excluded from taxable income, and hence free from federal, social security, and (in most cases) state taxes. There are limits on how much can be deducted ( $\$ 115$ per month for mass transit passes and $\$ 220$ for parking in 2008), but these limits are not relevant for our sample.

In order to allow employees to take advantage of Section 132(f), universities had to first make some changes in their payroll systems to allow for proper pre-tax deductions of parking pass (or mass transit pass) fees. ${ }^{5}$ As we show below, most schools we sampled introduced pre-tax parking for the 1998-1999 or 1999-2000 academic years. It is hard to say exactly how much tax revenue is lost by the exclusion of parking passes from income because we do not have an estimate of parking costs at facilities owned by employers. However, employee parking expenses in general lower tax revenue substantially. The Unites States Government (2007) estimates that the exclusion for reimbursed employee parking expenses will generate a $\$ 3.04$ billion revenue loss in 2008 , which is one of the largest revenue losses for IRC Section 132 fringe benefits (Gazur 2006). Mass transit pass exclusions lead to an estimated loss of

diplomats' countries.

${ }^{4}$ In fact, in 1985 a district court ruled against Marquette University's refund claim for employment taxes paid on the value of employee parking paid for via salary deduction in tax years 1973-1978 (Gazur 2006).

${ }^{5}$ The change in the tax code also insured that employer contributions to parking expenses did not have to be declared as income. So, if a university leased a parking spot for $\$ 100$ per month and sold a pass to an employee for $\$ 60$ per month, the employee would not have to pay taxes on the $\$ 40$ subsidy or the $\$ 60$ he spent on the pass. We do not know of any schools in our sample where this subsidy was relevant, however, because the universities generally own their parking facilities. 
$\$ 0.71$ billion. $^{6}$

\subsection{Supply and Demand of University Parking}

Figure 1 provides an example of the change in price and quantity of university parking passes before and after the 1998 tax code change. The University of Washington (UW) in Seattle provides unusually detailed transportation benefits pricing and usage data on their website (see http://www.washington.edu/commuterservices/programs/upass/reports.php). ${ }^{7}$ UW is in a central urban area known for traffic problems and congestion, so the school is unlikely to be typical. However, it does provide a useful example at a school where managing transportation is important and appears to be taken quite seriously. The figure shows that, from 1996 to 2005, the number of permits sold trended down slowly but steadily for both staff and students. On a percentage basis, the decrease was sharper for student permits. Faculty/staff permit sales were about five times that of students in 1996 and over eight times as large in 2005. We do not have quantity data for many of the schools in our sample. Note that such data would not be as useful as we would like, even if we had it, because sometimes parking passes are rationed. We do not know if this was the case at UW.

UW sells monthly parking permits to students, faculty, and staff. The price is the same for each of these groups. The figure shows the nominal monthly cost of this permit from 1996 through 2005. Pass prices increased at an average annual rate of $7 \%$. The increases were somewhat higher in the years after the introduction of the pre-tax plan (about 10\% in 2000, 2001, and 2002). The graph also shows how much a faculty member with a $25 \%$ marginal tax rate would have to earn in order to buy the monthly pass. ${ }^{8}$ The cost to this person of the pass dropped significantly with the introduction of the pre-tax plan, while the cost to students never decreased.

Figure 2 shows similar data for one of the few other schools for which we have both price and quantity data. This university, which we will call "School 2", sells a premium pass to

\footnotetext{
${ }^{6}$ See Unites States Government (2007) Table 19-1, page 288.

${ }^{7}$ All our UW data was gathered from public sources. Because we gathered data from the other schools without explicit permission to share it, we do not use the names of other schools.

${ }^{8}$ We believe that most parkers at universities in our sample will have had a marginal tax rate of at least $23.65 \%$ in 1998 . This corresponds to the $15 \%$ federal tax bracket, the employee portion of payroll taxes, and a $1 \%$ state income tax. Many faculty or staff will have had higher marginal tax rates.
} 


\section{University of Washington Parking Price and Quantity}

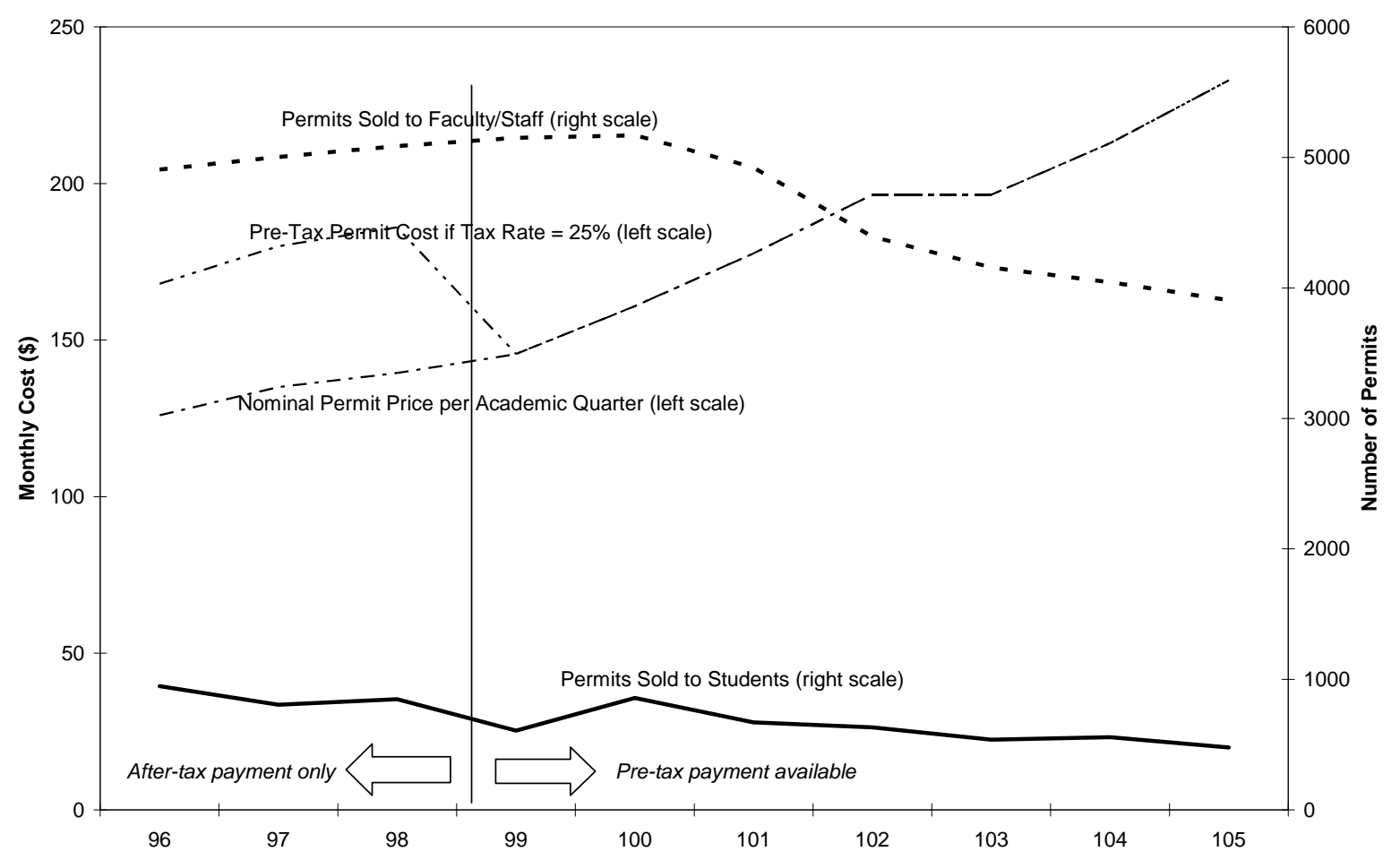

Figure 1: All data from $\mathrm{U}$ of $\mathrm{W}$ website. Permits are available to faculty, staff, and students and all groups pay the same price. 


\section{School 2 Parking Price and Quantity}

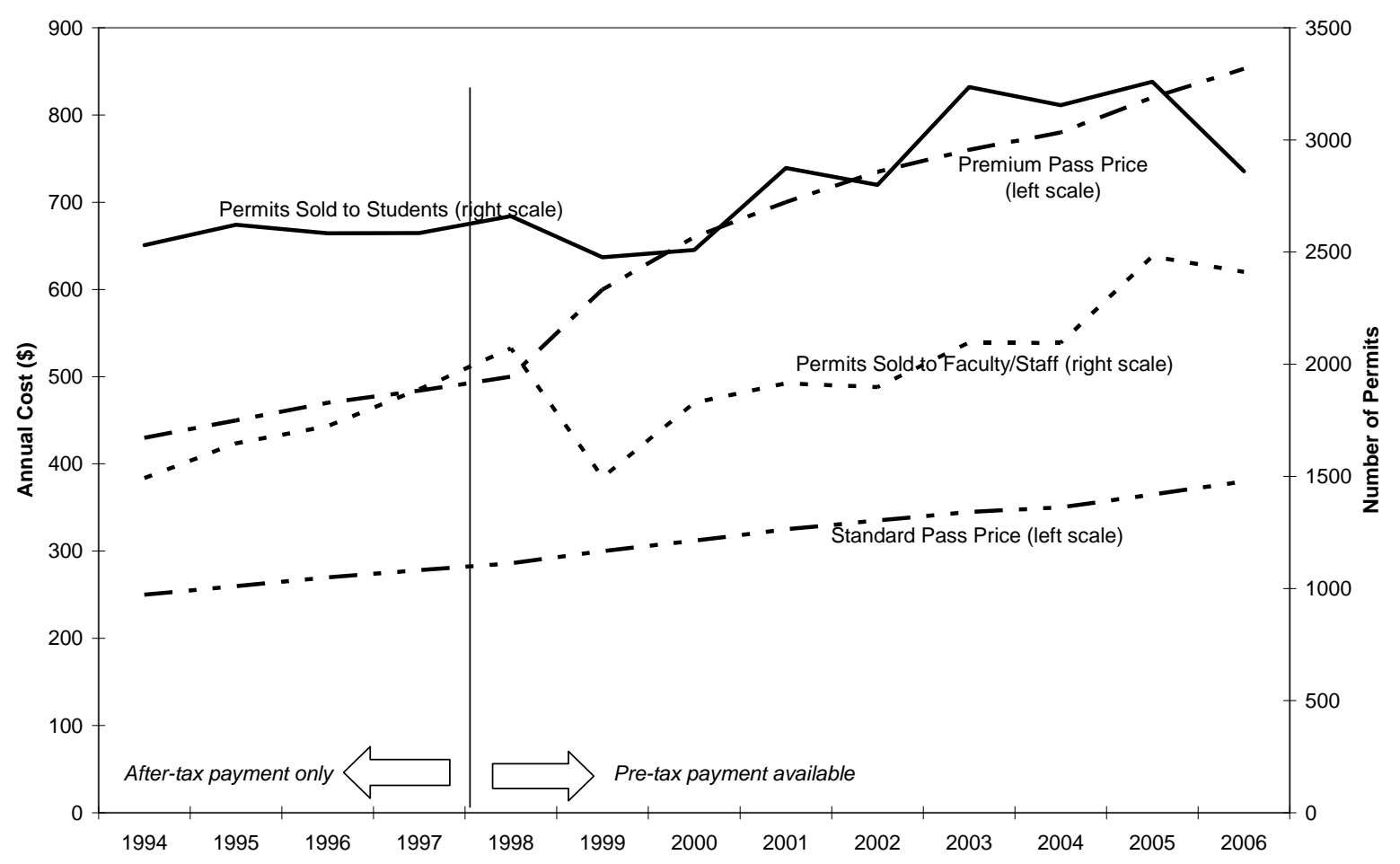

Figure 2: The school has two rates: premium permits are only available to faculty and staff. Standard permits are available to faculty, staff, and students and all groups pay the same price. 
faculty and staff only and standard pass to faculty, staff, and students. All purchasers of standard passes pay the same cash price, but, ever since 1998, faculty and staff have been able to pay for their parking passes with pre-tax dollars. The price of both types of passes has increased slowly but steadily. The premium pass price has increased at a $6 \%$ annual rate while the standard pass has increased 3.5\%. This university is more suburban than UW, which may explain why student parking demand is higher. ${ }^{9}$ More students than employees buy permits at this university. Faculty and staff permit sales took a one-time drop in 1999 for reasons that we do not know. The graphs of both UW and School 2 suggest that the change in the tax code may have had some effect on parking pass prices given slightly greater price increases after the new tax plans were enacted, but the effects do not appear to be large.

\section{Empirical Analysis}

\subsection{Data}

We gathered historical data for the academic years from 1990-1991 through 2006-2007 from the parking offices at universities. We sent emails, asking for historical parking rates and the date the university implemented a pre-tax payroll deduction parking plan, to the parking offices at all schools in the Pacific 10, Big 10, Ivy League, the University of California system, and the top 25 "National Universities" on the US News and World Report list of America's Best Colleges for 2007 (released in the Fall of 2006.) We received usable information from twenty-three universities covering one hundred and two different types of parking passes. This represents a response rate of approximately 50\%. A few of the nonrespondents indicated that they had tried, but failed, to find historical information. Others simply ignored our request and follow-up. We believe that the variation in response was due to historical accident as to who kept data and random differences in parking office helpfulness. Not all parking passes were offered in all years and not all schools could provide complete

\footnotetext{
${ }^{9}$ We have pass quantity information for two other schools. The first university, like School 2, is in a suburban location. A little over half of sales at this school are to faculty and staff. The second university, like UW, is in an urban location. A little over $90 \%$ of sales at this school are to faculty and staff.
} 
historical data for all passes, so we have a total of 1,395 parking pass/year observations. ${ }^{10}$ Of the 109 types of parking passes, forty-six (covering 548 pass/years) are available to faculty and staff only and forty-two (544 pass/years) are available to faculty, staff, and students. In the cases where employees and students can buy passes, students cannot get any tax advantage. The remaining twenty-one passes were not affected by the change in the tax code because sixteen of the passes (223 pass years) are available to students only and five passes (80 pass years) are daily or hourly rates for visitors. In order to implement a pre-tax payroll deduction parking plan, a university needs to make some adjustments to its payroll systems. Nine of the twenty-three schools implemented this plan for the 1998-1999 academic year, seven did so the following year, and three did so in 2000-2001.

Table 1 summarizes the prices of the passes. All prices have been converted to annual real $(\$ 2000)$ amounts and represent the price charged by the parking office. The amount an employee has to earn to purchase the pass may differ with whether the tax change has been put in place, but the prices analyzed here and throughout the paper are the amount the university receives (or withholds) from the employee.

The average pass sells for $\$ 459$, but there is considerable variation. One sixth of pass/years are priced under $\$ 100$ and $9 \%$ are priced above $\$ 1,000$. Prices are higher for passes that are limited to faculty and staff or to students because the universities that have offerings for a specific population are often in areas where land is expensive (such as Berkeley and Los Angeles.)

Figures 3 and 4 show the progression of real parking prices over the sample period for the four types of passes in Table 1. Figure 3 shows the average real price increase for each group. The graph shows that average increases were fairly steady for faculty-only passes with more variation in the other types, which is at least partially due to differences in sample sizes. Note that there is a noticeable bump up in prices at the time of the tax change in 1998. However, while we might expect this bump to be largest for faculty only passes, this group seems to have been the least affected. Figure 4 shows the average annual real price for each of the four groups. To keep the sample consistent, the graph is limited to those passes for which we have data for each year from 1995 to 2000. The graph does not reveal any major change in prices around the time of the new tax law.

\footnotetext{
${ }^{10}$ The regressions use a total of 1,391 pass/year observations. One pass had a price of zero for four years, so the log of the price is undefined over that time.
} 


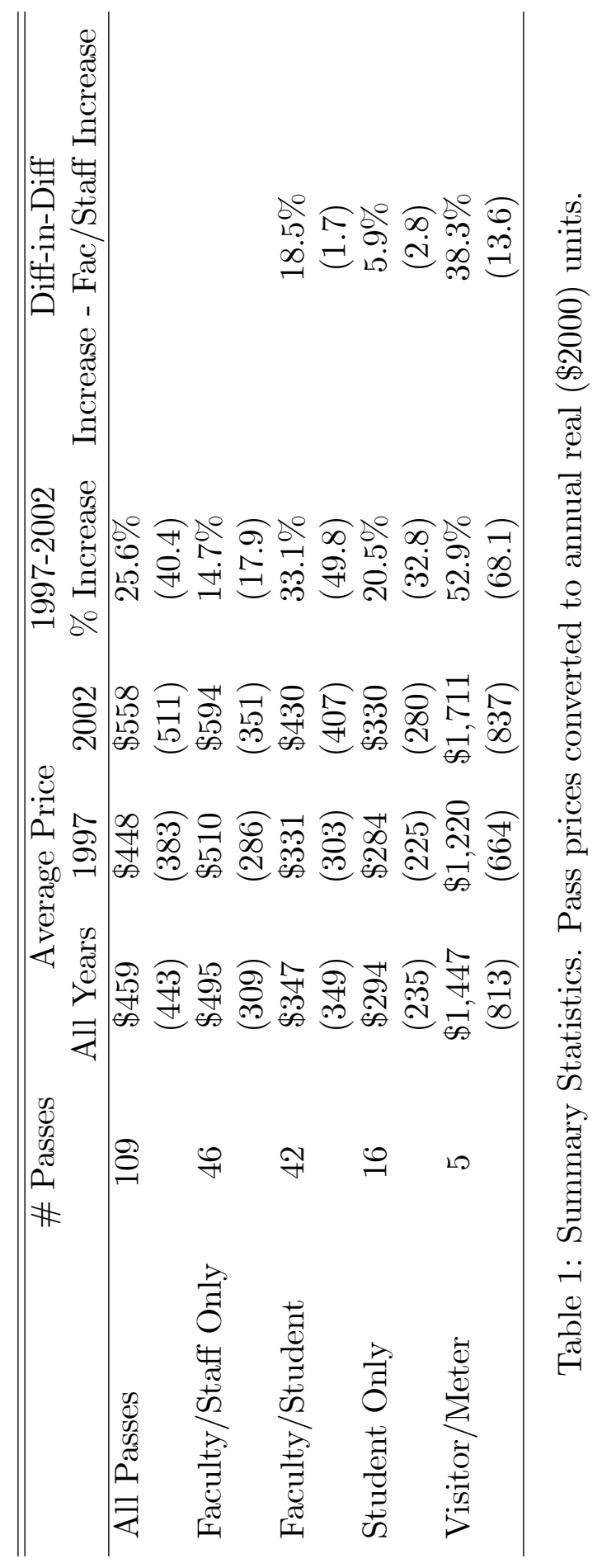




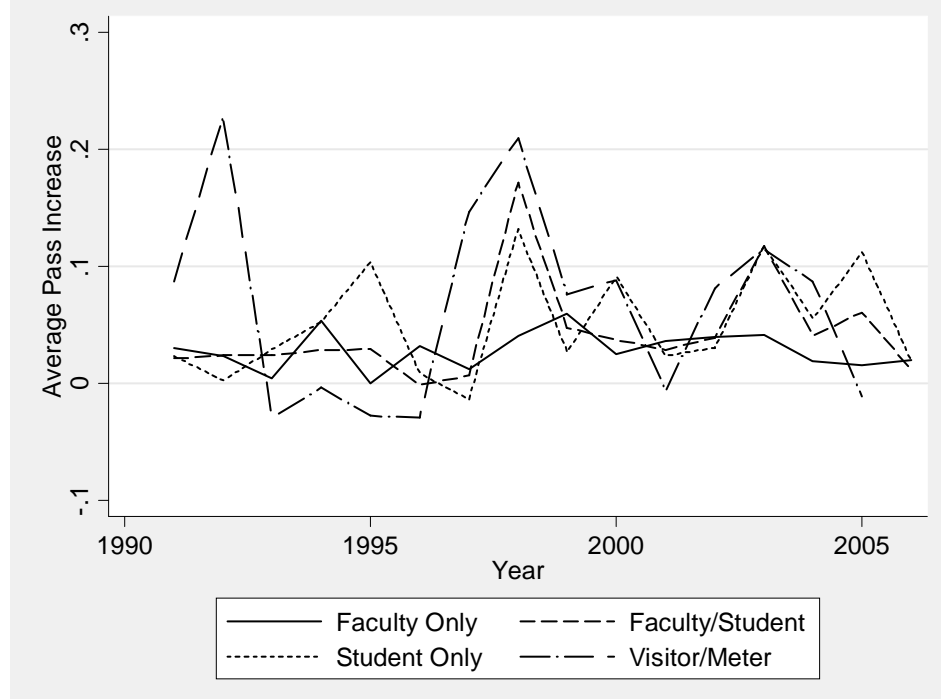

Figure 3: Average Real Price Increase. Displays the average annual price increase for each of the four types of parking permits.

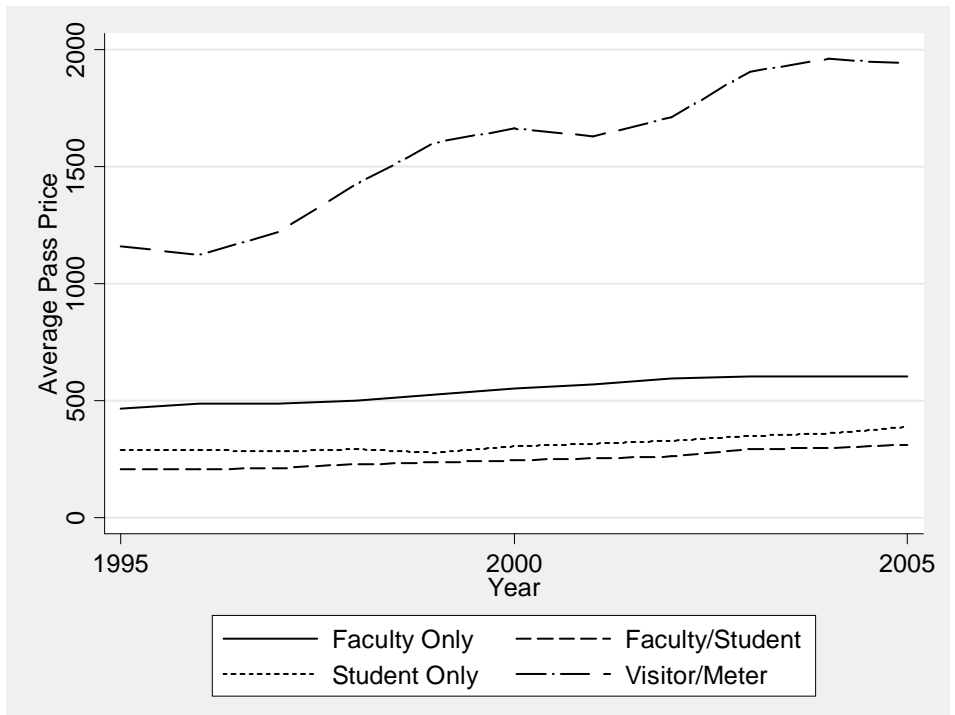

Figure 4: Average Real Pass Price. Displays the average annualized price (in \$2000) of each type of pass for all passes that where the price is available for all years from 1995-2005. 


\section{Analysis}

\subsection{Difference-in-Differences Estimates}

Our empirical analysis addresses two questions. First, to what extent did universities extract the surplus created through the transportation tax code change by increasing the parking prices they charge to employees? Second, did universities limit price increases to the population that could benefit from the tax change (that is, faculty and staff) or were students affected as well?

The right two columns of Table 1 provide some simple analysis to address these questions. The next to last column in the table shows the average price increase between 1997 and 2002 for all parking passes and each of the four types of passes. We find that the real price of the average pass increases by $25.6 \%$ in this five-year period. The average one-year price increase in the sample is $4.3 \%$, suggesting that the expected five-year price change is about $23.4 \%$ for the sample as a whole. The average of $25.6 \%$ for 1997 to 2002 appears typical.

There is no evidence to suggest that faculty and staff price increases around the tax change in 1998 were greater than the increases in prices of passes that were less affected by the tax change. In fact, passes available only to faculty and staff had the lowest rate of price

increase in this period surrounding the implementation of the new tax law. Student-only passes increased less than passes that can be bought by students and employees, but more than the prices of employee-only passes. The visitor sample, though small, had the greatest increase of all despite purchasers gaining no tax advantages.

\subsection{Regressions}

The visual evidence in Figures 3 and 4 and the simple difference-in-difference calculations in Table 1 do not suggest that universities extracted the surplus created by the 1998 tax law change, nor that prices went up more for those that could claim the tax benefit than for those that cannot. In this section, we do a more formal analysis looking at parking price changes at the exact time each school adopted a pre-tax parking pass plan.

We run regressions of the form

$$
p_{i t}=\delta_{i}+\theta t+\beta z_{i t}+\varepsilon_{i t}
$$


where $p_{i t}$ is the log of the price of parking pass $i$ in academic year $t, \delta_{i}$ is a fixed effect for pass $i$, and $\varepsilon$ is a random error term. The variable of interest is $z_{i t}$, which is an indicator variable that takes the value one if the school has implemented a pre-tax parking payment plan as of year $t$. The coefficient $\beta$ indicates the percentage increase in the pass price after the plan is adopted relative to before the plan is adopted, controlling for a linear time trend across plans. We also run regressions that relax the linearity assumption by replacing $t$ with a full set of year dummies. When we do this, we are identifying $\beta$ using variation across schools in when they implement a pre-tax parking plan. Note that in both cases our interpretation of $\beta$ assumes that, in the absence of the tax law change, the pattern of price changes would have been uncorrelated with pre-tax payment plan implementation dates.

Table 2 contains regression results. Column 1 shows that the baseline estimate of $\beta$ when fitting equation (1) is 0.089 , indicating that schools raised parking prices about $9 \%$ upon implementing a pre-tax payment plan. This coefficient is significant at the $1 \%$ level. Column 2 shows a similar regression, but includes a full set of year dummies. The coefficient is now less precisely estimated because we need to rely on variation in when individual schools implemented pre-tax plans. As a result, $\beta$ is estimated using only the few years where some schools have implemented pre-tax plans and others have not. Nonetheless the estimated coefficient is nearly unchanged and is significant at the $4 \%$ level. Note that these positive estimates of $\beta$ differ from the conclusions of the graphical and summary data above because, at many schools, price increases coincided with the implementation of the pre-tax plan rather than with the change in the tax code.

While the regressions in Columns 1 and 2 indicate that schools raised prices when the tax advantage was rolled out, it also implies that they did not raise them much. An increase in parking price of $9 \%$ is not very large for many employees. Consider a person with a marginal tax rate of $40 \%$ who is paying $\$ 500 /$ year (a little above the sample average) for a parking pass before the tax change. ${ }^{11}$ That person had to earn $\$ 833$, pre-tax, to pay for the parking pass. If the school raises the cost of the pass by $9 \%$, to $\$ 545$, the person has to earn $\$ 288$ less to pay for the pass and enjoys an additional $\$ 173$ of after-tax income. However, so far we have no reason to think students at that same school will not have to pay the additional

\footnotetext{
${ }^{11}$ For instance, at Yale in 1998 the average non-tenure track lecturer earned $\$ 47,288$ (Waters 2001). Filing single, such a lecturer would be in the $28 \%$ federal bracket, $5 \%$ Connecticut bracket, for a total marginal tax rate of $40.65 \%$ with payroll taxes.
} 


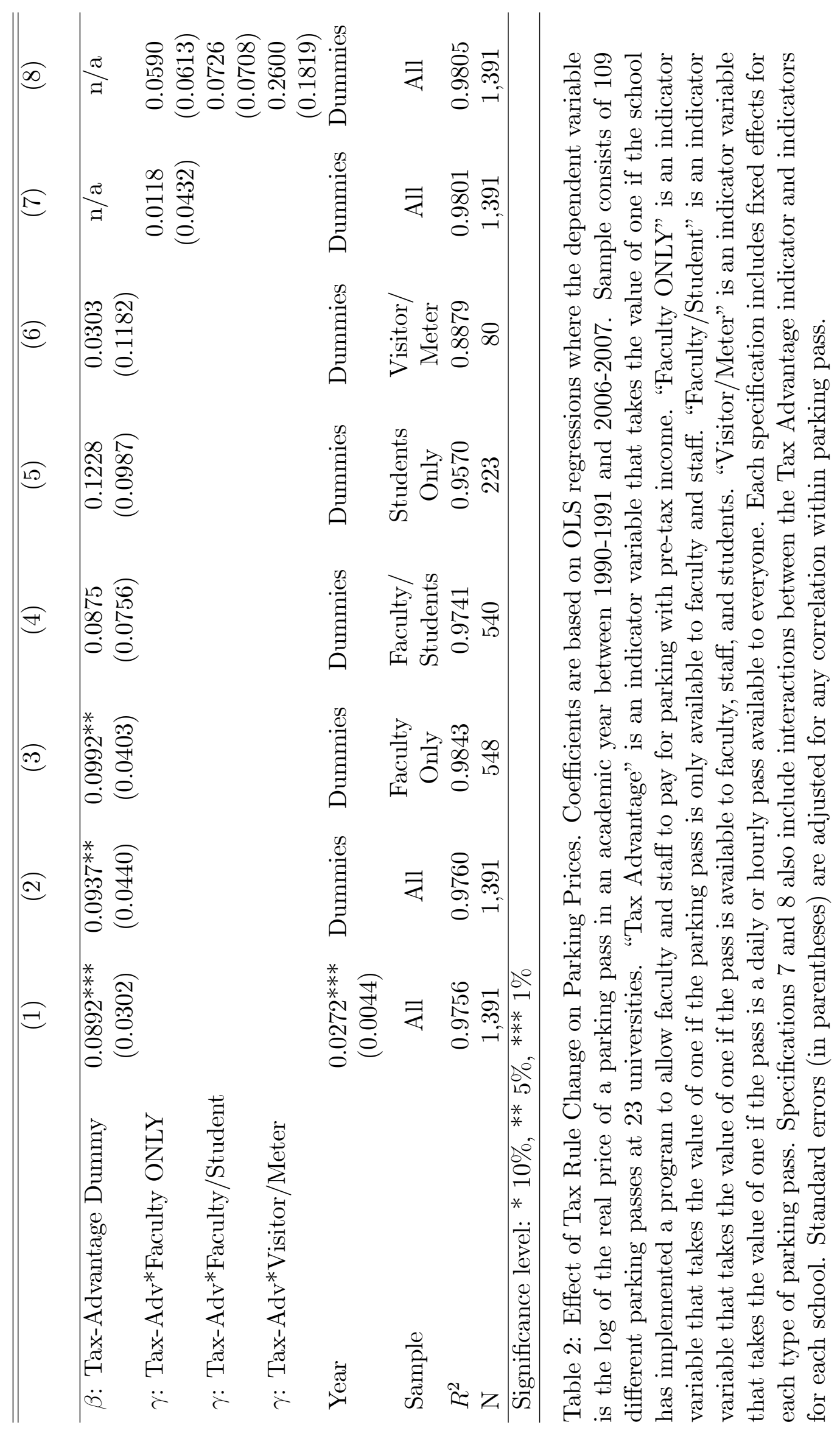


$\$ 45$ per year without the offsetting tax advantage. We now consider whether this is the case.

If schools are price discriminating, and costs are linear, we would expect that they will raise prices on faculty and staff permits after the tax change but not on student permits. However, if costs are convex (as Shoup (2005) suggests) then it is purely an empirical question how much student prices will change relative to faculty/staff prices. Columns 3-6 run the specification in equation (1) separately for each of the four permit types. The estimated effect of the tax law is higher for student permits. Column 3 indicates that faculty/staff permit prices went up by about $10 \%$ when the tax advantage came into effect while column 5 shows that prices for student permits went up by $12 \%$. Though this difference may not be statistically significant, it suggests that the effect of the tax law was not noticeably less for students.

The finding in columns 3 and 5 that the estimated effect of the tax law is highest for student-only permits could be due to the fact that schools that offer student-only permits are also schools that respond to the tax law change more aggressively across the board. In Column 7, we therefore change the specification in equation (1) slightly to

$$
p_{i t}=\delta_{i}+\theta_{t}+\beta_{j} z_{i t}+\gamma\left(z_{i t} * f_{i}\right)+\varepsilon_{i t}
$$

where $\beta_{j}$ is a coefficient specific to school $j$ that sells parking pass $i$, and $f_{i}$ is an indicator variable that takes the value one if parking plan $i$ is only available to faculty and staff. The coefficient $\gamma$ can be interpreted as the additional percentage change in parking prices after pre-tax plans are implemented for employee-only parking passes, relative to the other three types of passes. Note that this interpretation assumes that the different types of parking passes would on average have had similar patterns of price changes in the absence of the tax law change. ${ }^{12}$ To make sure we compare passes rather than schools when we estimate $\gamma$, we want to focus on within-school differences between faculty/staff price increases and other permit price increases. So we estimate a vector of school specific coefficients $\left(\beta_{j}\right)$ of the tax-advantage variable $\left(z_{i t}\right)$ when we estimate $(2)$. Column 7 coefficients indicate a negligible and insignificant difference in price adjustment for those that can take advantage of the tax change relative to those that cannot. Column 8 runs a similar specification, but

\footnotetext{
${ }^{12}$ This assumption can be relaxed by including a full set of year dummies for each type of parking pass, which yields similar results.
} 
simultaneously compares faculty-only, faculty/student, and visitor price increases to studentonly price increases. ${ }^{13}$ The difference between the four types of parking passes is statistically insignificant. Including all types of passes in one regression leads to the same conclusion: untargeted across-the-board price increases cannot be rejected.

In unreported analyses, we did several robustness checks and looked at factors that might explain variation in university parking prices. We did not find that being a public university made a difference, for example. Also, we found that our conclusions are basically unchanged when using school (rather than parking plan) fixed effects, or when including school-specific linear time-trends (rather than a single linear time-trend). Our analysis so far has assumed that any price effects of the pre-tax plans started at the same time as the plan. However, there could be some delay in the price effect if, for example, a school set its prices and then decided to quickly implement a tax-free plan so that employees could capture the benefits of the plan immediately. We reran the regressions dropping the first year of each schools' pre-tax plan, but found it did not materially effect our results. Finally, we used a more conservative approach of clustering the standard errors at the school, rather than parking pass, level. This did not affect any of our conclusions, either.

Our identification strategy implicitly assumes that there was no change in the environment that affected parking prices and was correlated with the implementation of parking permit pre-tax payment plans. However, in response to the tax law changes made in TRA97 and TEA-21, many universities in our sample introduced pre-tax payment plans for mass transit passes at the same time as for parking permits. If mass transit is a close substitute for parking, the reduction in after-tax mass transit prices could have limited university parking departments ability to raise parking prices. This would imply that our estimates underestimate the effect of the change in tax treatment for parking passes. We find this unlikely however, because the effect of the tax change is nearly identical in urban and rural sub-samples. If the mass transit pre-tax payment plan were limiting parking permit price increases, we would expect to see a larger price increase on rural campuses which have limited access to mass transit. ${ }^{14}$

\footnotetext{
${ }^{13}$ Grouping student-only and visitor/meter passes together pushes point estimates of $\gamma$ for faculty-only and faculty/student passes closer to zero.

${ }^{14}$ Note that we expect that the increased availability of parking provided by competitive third parties in urban settings would reinforce rather than mask this effect. The presence of close substitutes should make
} 


\subsection{Interpretation}

The regression results lead to several conclusions and speculations. First, as noted above, the price changes made by these schools after the tax law change leave significant surplus to those buying parking permits. The increases in parking permit rates are much lower than the tax benefits to many employees. Universities could be extracting some of this surplus back in the form of lower wages, but it is hard to see why they would adjust the wage rather than the permit price. In any case, making the reasonable assumption that universities did not change the salaries of those who buy parking permits relative to those that did not as a result of the tax change, we can at least conclude that the tax law change gave some amount of surplus to faculty and staff that buy parking passes relative to those that do not.

Our second conclusion is that students lost surplus as a result of the tax change. ${ }^{15}$ Universities apparently did not target the price changes to those parties that stood to benefit from the tax changes, despite the fact that 20 of 23 universities in our sample price discriminate between faculty and students. Facing price increases, students could have bought cheaper (and, therefore, more remote) passes or found alternative transportation. But given they were now choosing an alternative from an inferior set of choices, they were clearly worse off.

Third, we are struck by the apparent limitations on price discrimination of university parking permits. While some universities have a wide range of permit options, others have very few choices. We found no evidence of additional permit choices being offered when the tax law was changed. While tax rates are likely to be quite variable for different parkers at a university, we see no differential price treatment based on how the tax benefits affected individuals. Universities could have added more variation in the prices, either based directly on income or other variables (such as demand for premium parking) that are likely to be correlated with marginal tax rates. In this case, they might have been able to increase prices in line with employee tax rates and employees may have sorted themselves accordingly. This appears to be how investors segment into taxable and tax-free bonds, where the differences in yields imply investors with tax rates of $25 \%$ or more choose tax-free bonds (see Green

\footnotetext{
residual parking demand more elastic, and hence reduce optimal price increases.

${ }^{15}$ Again, there could have been offsetting differences in terms of tuition or stipends. But, at the least, students who bought permits lost surplus relative to those that do not.
} 
(1993)).

We can only speculate as to why university parking prices reacted the way they did to the tax law change. We discuss three specific explanations for the small but universal price increases: (1) Parking departments maximize profits and elasticity of demand is high. (2) Parking departments maximize profits but the tax law change had low salience. (3) Parking departments practice average cost pricing. We favor the latter two explanations over the first because we do not believe parking demand is sufficiently elastic to support the first explanation (although we have only anecdotal evidence for this).

(1) Profit maximization and high elasticity: Suppose a university finds that employees' decisions to take or keep a job are not based on parking pass prices, and directs its parking department to maximize parking profits in order to maximize the financial resources available for pursuing the university's educational objectives. Moreover, assume that the university can charge students and employees different prices. Both of our primary findings, that student prices increase as much as faculty prices with the tax law change, and that faculty prices increase by about 8-10\% are potentially consistent with this scenario. However, an $8-10 \%$ faculty and staff price increase is only consistent with profit maximization if faculty and staff parking pass sales increase substantially.

If all employees have the same marginal tax rate $\tau$, then the tax law change increases the employee marginal revenue curve by a factor of $\frac{1}{1-\tau}$. Unless marginal parking costs are zero, it will be optimal to increase aggregate permit sales, and in particular to increase faculty and staff permit sales. If the marginal cost of parking is constant, then this does not effect the cost of serving students and the university should not change student prices. However, if there is a fixed parking capacity or marginal costs are increasing (as Shoup (2005) suggests), then the marginal cost of serving students increases and so should student prices. This implies that, despite a university's ability to price discriminate, student price increases are a natural consequence of parking department profit maximization and that student price increases need not be smaller than those for faculty and staff. For example, if both students and employees have constant elasticity of demand then student and employee permit prices will increase by the same percentage. ${ }^{16}$ In short, the fact that student prices increase as

\footnotetext{
${ }^{16}$ Suppose student demand is $P_{s}=A_{s} Q_{s}^{1 / \eta_{s}}$ and faculty demand is $P_{f}=A_{f} Q_{f}^{1 / \eta_{f}}$. Student elasticity is $\eta_{s}$ and faculty elasticity is $\eta_{f}$. The tax law change inflates faculty demand by a factor $\frac{1}{1-\tau}$, but this does not change their elasticity of demand. Profit maximization equates marginal revenue across both groups both
} 
much as faculty and staff prices is potentially consistent with parking department profit maximization.

If all parkers have a marginal tax rate of at least $\tau$, then the university always has the option of increasing employee permit prices by $\frac{1}{1-\tau}$ after the tax law change. This increases revenues from employees who bought before the tax law change by $\frac{1}{1-\tau}$, and could increase permit sales to employees with marginal tax rates above $\tau$. This is true even if nonuniversity owned garages supply parking competitively near campus, since universities need not establish pre-tax payment plans for these garages. The optimal employee permit price increase could be either higher or lower than $\frac{1}{1-\tau} \cdot{ }^{17}$ However, a smaller price increase can only be optimal if employee parking demand is sufficiently elastic that total employee permit revenues still increase by at least $\frac{1}{1-\tau}$. In particular, it can be shown that if the university finds it optimal to increase nominal employee parking prices by a factor of $\alpha \leq \frac{1}{1-\tau}$, then employee permit sales must increase by a factor of at least $\left(\frac{1}{1-\tau} \frac{1}{\alpha}\right){ }^{18}$ For instance, if the minimum tax rate is $25 \%$, then a nominal employee-permit price increase of $10 \%$ after the tax law change is only consistent with profit maximization if employee-permit sales increase by at least $21 \%$. Although we have quantity time series data for only three schools, we have no evidence that parking demand spiked after the tax law change. This indicates to us that elasticity is not high enough to justify such small price increases. (In fact, faculty and staff permit sales fell at School 2, as seen in Figure 2, despite a drop in after-tax permit prices following the tax law change.)

In summary, our empirical findings can be reconciled with a model of very highly elastic university parking. However, while we are not able to estimate parking elasticity carefully, the indications that we do have suggest that very high elasticity is unlikely to explain our results.

before and after the tax law change. Because student and faculty elasticities are constant in both quantity and the tax treatment, price always remains proportional to marginal revenue: $M R=P(1+1 / \eta)$. Hence the percent change in price is equal to the percent change in $\mathrm{MR}$, and therefore equal across both groups.

\footnotetext{
${ }^{17}$ All that can be said without more information about demand is that the optimal price increase is no higher than one over one minus the highest marginal tax rate.

${ }^{18}$ Denote the initial employee price $P_{0}$. Absent a student market, an employee price $\alpha P_{0}$ which is less than $\frac{1}{1-\tau} P_{0}$ leads to weakly higher sales and costs than a price equal to $\frac{1}{1-\tau} P_{0}$. Hence to be more profitable it must yield higher revenues: $\alpha P_{0} Q\left(\alpha P_{0}\right) \geq \frac{1}{1-\tau} P_{0} Q\left(\frac{1}{1-\tau} P_{0}\right)$. This implies: $\frac{Q\left(\alpha P_{0}\right)}{Q\left(P_{0}\right)} \geq \frac{1}{1-\tau} \frac{1}{\alpha} \frac{Q\left(\frac{1}{1-\tau} P_{0}\right)}{Q\left(P_{0}\right)} \geq \frac{1}{1-\tau} \frac{1}{\alpha}$. A similar argument shows the same result in the presence of a student market.
} 
(2) Profit maximization and low salience: Another possible explanation of the seemingly small price reaction to the parking tax benefits is limited salience of the change. If buyers of permits do not realize that their employer adopted a pre-tax plan, then they will overestimate the effective price of permits. Thus a low salience of the tax-deduction will lead to fewer sales and smaller price increases than would otherwise be expected. Finkelstein (2007) and Chetty, Looney and Kroft (2008) show that reducing the salience of a tax (rather than a tax deduction) leads to higher prices and demand. Finkelstein (2007) shows that highway toll rates increase in response to a decrease in tax salience brought on by the implementation of electronic toll collection. Chetty et al. (2008) show that consumer demand is higher if pre-tax prices are posted than when posted prices include tax, even if the end price is exactly the same. In these contexts, sellers of a product had an incentive to hide a tax from consumers in order to keep demand high.

In the parking context, salience would have the opposite effect on prices and sales because the salience problem is related to a tax deduction rather than to a tax. Given the sometimes large amount of revenue available from increasing parking fees, universities have strong incentives to raise the salience of the tax law change. They might engage in marketing campaigns to communicate the value of this benefit if they felt salience was inhibiting their ability to raise prices. It seems quite possible that limited salience is at least a contributing factor to universities' limited price response to the parking tax change, but we cannot assess the exact degree to which salience of the parking tax change affects pricing.

(3) Average cost pricing: The fact that universities left so much of the value of the tax change to employees is consistent with the use of "average cost pricing" policies. Though it is difficult to generate an economic model that justifies this practice, many university parking offices operate under the stated goal of breaking even. ${ }^{19}$ Shoup (2005) focuses on UCLA's implementation of average cost pricing for parking. We have spoken with administrators in other parking offices that use a similar approach and other schools suggest they use this method in the literature on their websites. The basic idea of average cost pricing is that the transportation office is told to set fees for parking (and, in some cases, other transportation

\footnotetext{
${ }^{19}$ The unofficial goal may be empire building, in the sense of maximizing permits sold or spaces managed, subject to a university imposed constraint that the parking office not lose money. A parking department with only one permit price would then charge average cost. However, this objective will lead parking departments that can set multiple permit prices to price discriminate to extract money from high value parkers to subsidize the cost of parking to low-value parkers not only below marginal cost, but below average cost as well.
} 
services such as shuttle bus rides) so as to cover the costs of providing parking spaces and other transportation. Some schools attempt to recover the costs of capital while others price so as to merely break even in terms of operating expenses.

If a school is using average cost pricing for parking, then the tax law change should have little immediate effect on permit prices. However, given a substantial reduction in effective parking prices for at least some university employees, demand will increase after the tax law change. As Shoup (2005) discusses, the marginal price to build a parking space is typically far higher than the average cost of existing space, so prices would likely have to go up to sustain the average cost pricing scheme. ${ }^{20}$ Therefore, we would expect universities that use average cost pricing for parking to leave their parking prices unchanged, or increase them slightly, after the tax law change. ${ }^{21}$ This pattern appears consistent with our empirical results.

Nearly all universities in our sample price discriminate between faculty/staff and students. Note that, in addition to changing student and faculty prices at the same rate, rigidity of price discrimination policies is also found in the fact that almost no schools added additional types of parking permits or separated faculty/staff and student passes when both populations were eligible to purchase them. On the one hand, it is not clear how a parking department that sets prices with the stated goal to break even determines the price difference between faculty/staff and student permits. On the other hand, the fact that students and faculty were not differentially affected by the tax change could be driven by budget balanced pricing policies, as parking offices may be indifferent to where the necessary revenue comes from.

\section{Conclusions}

According to the Unites States Government (2007), the United States will forgo $\$ 3.04$ billion in 2008 tax revenues due to pre-tax employee parking programs made possible by TRA-97. One possible motivation for this national expense is to remove an incentive for employers to avoid paying taxes by providing employees with free parking. By removing such an incentive,

\footnotetext{
${ }^{20}$ Average costs that include administrative costs could still fall if fixed administrative costs are large enough.

${ }^{21} \mathrm{~A}$ slight increase is expected if either the increase in demand is not very large, or the difference between marginal cost and average cost is not very large.
} 
the change in tax law could have increased effective parking prices, and reduced inefficiently high parking and related traffic congestion. Our results suggest that this was not the outcome in university parking lots. We find that nominal university parking rates go up only 8-10\% as the tax advantage becomes available, so effective parking prices fall for employees with marginal tax rates above $11 \%$. Although we cannot be definitive without quantity or wage data, under the reasonable assumption that wages were unaffected by the change in tax code and that employee parking is relatively inelastic, these moderate price increases imply that universities capture only a small portion of the tax benefit. Instead, because price increases are across the board, the primary beneficiaries are faculty and staff who buy permits and have high marginal tax rates, while students who buy permits are actually worse off. While the lack of discrimination between faculty and students can be reconciled with parking department profit maximization, the small price increases for faculty and staff suggest that, if parking prices maximize university profit, parking demand must be highly elastic or the tax law changes must have very low salience with employees. The results are generally consistent with the claim by Shoup (2005), and many parking departments themselves, that university parking departments use average cost pricing. 


\section{References}

Andreoni, James and A. Abigail Payne, "Do Government Grants to Private Charities Crowd Out Giving or Fund-raising?," The American Economic Review, 2003, 93, 792-812.

Arbatskay, Maria, Kaushik Mukhopadhaya, and Eric Rasmusen, "The Parking Lot Problem," 2006. Emory University Working Paper.

Berger, Philip G., "Explicit and Implicit Tax Effects of the R\&D Tax Credit," Journal of Accounting Research, 1993, 31, 141-171.

Chetty, Raj, Adam Looney, and Kory Kroft, "Salience and Taxation: Theory and Evidence," 2008. University of California at Berkeley Working Paper.

Finkelstein, Amy, "E-ZTax: Tax Salience and Tax Rates," 2007. MIT Working Paper.

Fisman, Raymond and Edward Miguel, "Corruption, Norms, and Legal Enforcement: Evidence from Diplomatic Parking Tickets," Journal of Political Economy, 2007, 115, 1020-1048.

Gazur, Wayne M., "Assessing Internal Revenue Code 132 After Twenty Years," Virginia Tax Review, 2006, 25, 977-1046.

Goolsbee, Austan, "Does Government R\&D Policy Mainly Benefit Scientists and Engineers?," American Economic Review, 1998, 88, 298-302.

, "Investment Tax Incentives, Prices, and the Supply of Capital Goods," Quarterly Journal of Economics, 1998, 113, 121-148.

Green, Richard C., "A Simple Model of the Taxable and Tax-Exempt Yield Curves," Review of Financial Studies, 1993, 6, 233-264.

Marino, Anthony M. and Jan Zabojnik, "A Rent Extraction View of Employee Discounts and Pricing," Journal of Labor Economics, 2008. Forthcoming.

Oyer, Paul, "Salary or Benefits?," Research in Labor Economics, 2008. Forthcoming.

Poterba, James M., "Tax Subsidies to Owner-Occupied Housing: An Asset-Market Approach," Quarterly Journal of Economics, 1984, 99, 729-752.

Shoup, Donald, "Parking on a Smart Campus," in Daniel Mitchell, ed., California Policy Options 2005, Los Angeles: UCLA School of Public Affairs, 2005. 
Susin, Scott, "Rent Vouchers and the Price of Low-Income Housing," Journal of Public Economics, 2002, 83, 109-152.

Unites States Government, Analytical Perspectives, Budget of the Unites States Government, Fiscal Year 2008, Washington: US Government Printing Office, 2007.

Waters, Beverly, A Yale Book of Numbers 1976-2000, New Haven, CT: Yale Office of Institutional Research, 2001. 